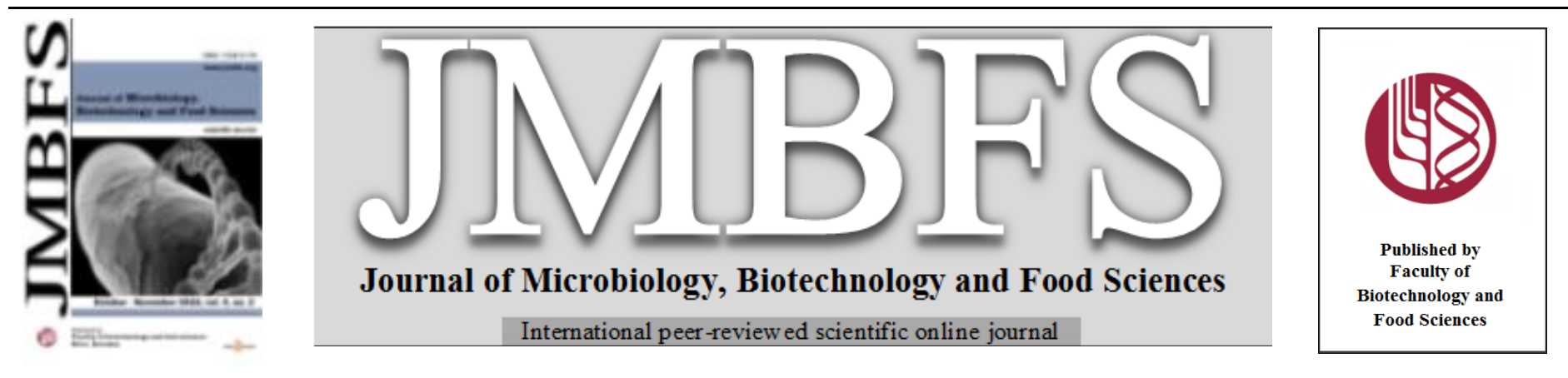

\title{
EFFECT OF GAC FRUIT POWDER ON QUALITY AND NITROSATION ACTIVITY OF MEAT PRODUCT
}

\author{
Pasakorn Uearreeloet ${ }^{1}$, Nattaya Konsue $*^{1}$ \\ Address(es): Nattaya Konsue, \\ ${ }^{1}$ Program in Food Technology, School of Agro-Industry, Mae Fah Luang University, 57100, Chiang Rai, Thailand, +66-53916738.
}

*Corresponding author: nattaya.kon@mfu.ac.th

doi: 10.15414/jmbfs.2016.6.2.786-790

\section{ARTICLE INFO}

Received 30. 4. 2016

Revised 13. 5. 2016

Accepted 12. 7. 2016

Published 3. 10. 2016

Regular article open ${ }_{\text {ACCESS }}$

\begin{abstract}
Nitrite is important for meat product quality especially for color stabilization. However, toxicity of nitrite according to nitrosation reaction raises interest of many researchers. To improve the quality and safety of meat product, nitrite was substituted with freeze dried gac fruit aril (GP). Frankfurters were produced with the combination of $50-150 \mathrm{mg} / \mathrm{kg}$ sodium nitrite and $0-4 \% \mathrm{GP}$ and stored at $4^{\circ} \mathrm{C}$. Color, $\mathrm{pH}$ and lipid oxidation (thiobarbituric acid reactive substances, TBARS) were determined weekly for 4 weeks whereas sensorial qualities were evaluated after cold storage at $4^{\circ} \mathrm{C}$ for one day. Aqueous determination of $\mathrm{N}$-nitrosodimethylamine (NDMA) content was carried out by high-performance liquid chromatography (HPLC) at day zero before and after a two-step in vitro digestion. The results showed that replacement of nitrite with GP caused slightly increase in $\mathrm{pH}$ of frankfurter in a concentration dependent manner and falling of $\mathrm{pH}$ values were observed after 21 days storage. TBARS values also elevated but only when the highest level of GP (4\%) was employed and storage time reached 28 days. Moreover, GP resulted in declining of $\mathrm{L}^{*}$ (lightness) and greater of a* (redness) and $\mathrm{b}^{*}$ (yellowness) values of frankfurter which these were paralleled with increasing of color acceptability score evaluated by panelists. These color values were unchanged throughout storage period at 4\% GP content. Finally, NDMA only occurred after in vitro digestion and tended to increase in the presence of GP. It can be concluded that GP successfully improved color stability and acceptability of frankfurter. However, over dose of GP incorporation (4\%) led to increasing of lipid oxidation and nitrosation reaction.
\end{abstract}

\section{INTRODUCTION}

Momordica Cochinchinensis Spreng is commonly known as gac. It is originated in Southeast Asia and most typical in Myanmar, Thailand, Laos, Bangladesh, Malaysia, Philippines, and Vietnam. All parts of the plant have attracted interest of researchers in recent years and are used for medicinal and nutritional purposes. The young fruit is rich in vitamin $\mathrm{C}$, calcium, and fiber whereas gac aril of fully mature fruit contains superior amount of lycopene, flavonoid, and phenolic compounds and, therefore, high in antioxidant activities (West and Poortvliet, 1993). Being reported as a rich source of lycopene, compared to many fruits and vegetables especially tomato (Kubola and Siriamornpun, 2011), gac aril has intense red color which makes it a promising natural food colorant. Gac oil powder could be successfully incorporated into food products such as yogurt, pasteurized milk and cake to improve color retention, $\beta$-carotene and lycopene content (Kha et al., 2015). Moreover, lycopene is a potent antioxidant and plays an important role in prevention of many diseases such as cancer, cardiovascular diseases as well as modulation of immune system (Aust $\boldsymbol{e t}$ al., 2003).

The reaction of nitrite with pigment in meat forms stable red color which is essential to consumer likeliness. The European Food Safety Authority (EFSA) stated that addition of nitrite is necessary to inhibit pathogenic microorganisms in particular Clostridium botulinum and the maximum level is $150 \mathrm{mg} / \mathrm{kg}$ (FAO/WHO, 1996). However, nitrite or nitrogen oxides can react with secondary amines in meat to form nitrosamine, the reaction of which is known as nitrosation. A multistep process of nitrosation includes nitrous acid $\left(\mathrm{HNO}_{2}\right)$ production by the addition of a hydrogen ion to the nitrite ion in acidic condition of gastric cavity following with water molecules removed to form an ultimate toxicant, nitrosonium ion $(\mathrm{N} \equiv \mathrm{O}+)$. Nitrosamine has shown toxicological significance in human by formation of DNA adducts and its carcinogenic effect has been well established. Ohshima and Bartsch (Ohshima and Bartsch, 1999) demonstrated that suitable condition of nitrosation rather involved with many factors including $\mathrm{pH}$, amine substrate and nitrosating agent. Color is an important factor for the customer acceptance in meat-based food, therefore, many researchers have studied the stability of color of fresh and processed meat and optimized the use of nitrite in order to maintain good color and enhance product safety (Feiner, 2009). Inhibition of nitrosation has been reported; the addition of nitrosation inhibitor such as ascorbic acid, isothiocyanate and tocopherols to the curing mixture has resulted in significant reduction in the levels of nitrosamine (Biaudet et al., 1996). Meat products contain high lipid content that makes it prone to lipid oxidation. Not only primary cause of flavour changes, lipid oxidation is considered as an important factor for color and nutritive value alteration in meat products as well as generation of toxic and carcinogenic compounds (Jensen et al., 1998). Control of oxidation in meat product has become increasingly important to prevent quality deterioration especially during chilling storage of processed meat.

Therefore, this study was aimed to evaluate the possibility of gac aril powder application as a natural colorant in meat products and its effects on product quality. Moreover, degree of nitrite substitution on nitrosamine content in meat products before and after enzymatic in vitro digestion was also determined.

\section{MATERIAL AND METHODS}

\section{Chemicals and reagents}

Pancreatin, pepsin, N-nitrosodimethylamine, trichloroacetic acid (99\%), 1,1,3,3 tetramethoxypropane (99\%), 2-Thiobarbituric acid (98\%), HPLC grade methanol and acetonitrile were obtained from Sigma-Aldrich (Singapore). HPLC grade water was acquired from Milli-Q water purification system (Millipore, Bedford, USA.).

\section{Freeze dried gac fruit aril preparation}

Fully mature gac fruits were purchased from local farm in Chiang Rai, Thailand. $\mathrm{Gac}$ arils were removed from the seeds and milled in a blender to obtain homogenous aril. The aril paste was freshly frozen at $-40{ }^{\circ} \mathrm{C}$. Then under freezedrying system at $10^{-2} \mathrm{~Pa}$, the frozen aril was dried overnight to obtain pure gac aril powder. The powder was blended and sieved to achieve homogenous fine powder. Gac fruit powder (GP) was stored in a cool dry place for further utilization. 


\section{Frankfurter preparation}

Production of frankfurters was carried out according to Laemthong Food Products Co. Ltd. procedure. The frankfurters were divided into 9 treatments with different levels of nitrite $(50,100$, and $150 \mathrm{mg} / \mathrm{kg})$ and freeze dried gac fruit aril $(0,2$, and $4 \mathrm{~g} / 100 \mathrm{~g})$. Briefly, lean pork $(80 \% \mathrm{w} / \mathrm{w})$ and pork fat $(20 \% \mathrm{w} / \mathrm{w})$ purchased from local market were chilled and finely chopped in a bowl chopper at the holding temperature below $5^{\circ} \mathrm{C}$ prior to all ingredients were added including nitrite and GP. Liquid smoke at $75{ }^{\circ} \mathrm{C}$ for $30 \mathrm{~min}$ was employed after casing in a $10 \mathrm{~cm}$ long with $3 \mathrm{~cm}$ diameter following with cooking in $100{ }^{\circ} \mathrm{C}$ water bath until internal temperature reached $80{ }^{\circ} \mathrm{C}$. Cooked frankfurters were instantaneously cooled down in ice-cold water and vacuum packed. Samples were stored at $4{ }^{\circ} \mathrm{C}$ and taken at day $0,7,14,21$, and 28 for physicochemical analysis. Sensory evaluation was performed at one day after storage.

\section{Color measurement}

Determination of color was carried out as described previously (Eyiler and Oztan, 2011). Redness ( $\left.a^{*}\right)$, yellowness $\left(b^{*}\right)$, and lightness $\left(\mathrm{L}^{*}\right)$ of inner cuts of samples were achieved by using Hunter Lab Color Quest XE (Hunter Associates Laboratory, Inc., USA.)

\section{pH measurement}

A 10-g of sample was homogenized at 5,000 rpm with $50 \mathrm{~mL}$ of distilled water The homogenate was filtered through a filter paper and then $\mathrm{pH}$ of sample was assessed by using Digital $\mathrm{pH}$-meter.

\section{Determination of thiobarbituric acid reactive substances (TBARS)}

TBARS assay was slightly modified as described previously (Meineri $\boldsymbol{e t}$ al. 2013). Samples $(10 \mathrm{~g})$ were homogenized with $10 \%$ trichloroacetic acid $(20 \mathrm{~mL})$ The homogenate was centrifuged at $600 \mathrm{rpm}$ for $5 \mathrm{~min}$ at controlled temperature of $4{ }^{\circ} \mathrm{C}$. The supernatant was subsequently filtered through Whatman No.1 filter paper. To $1 \mathrm{~mL}$ of filtrate, $1 \mathrm{~mL}$ of a $0.02 \mathrm{M} 2$-thiobarbituric acid solution (TBA) was added prior to heating up in boiling water for $20 \mathrm{~min}$. The pink color of sample was developed according to the reaction of TBA and oxidation products and was spectrophotometric measured at $538 \mathrm{~nm}$. The content of malondialdehyde (MDA) was expressed as $\mathrm{mg} \mathrm{MDA} / \mathrm{kg}$ calculated using calibration curve of 1,1,3,3-tetramethoxypropane standard.

\section{In vitro digestion}

The method for in vitro digestion was modified from Boisen and Fernández (1997). The two steps digestion mimicking the protein digestion processes in the stomach and small intestine was carried out. Firstly, $0.1 \mathrm{M}$ of $\mathrm{pH} 6.0$ phosphate buffer was added into the flask containing ground sample $(0.5 \mathrm{~g})$. The mixture was continuously mixed using magnetic stirrer. A-10 $\mathrm{mL} \mathrm{HCl}(0.2 \mathrm{M})$ was added prior to the $\mathrm{pH}$ adjusted to 2.0. The combination was digested for $2 \mathrm{~h}$ at 39 ${ }^{\circ} \mathrm{C}$ with pepsin $(25 \mathrm{mg} / \mathrm{mL})$ in the presence of $0.5 \mathrm{~mL}$ of $0.5 \%$ chloramphenicol in ethanol. Subsequently, $10 \mathrm{~mL}$ of $0.2 \mathrm{M}$ phosphate buffer $(\mathrm{pH} 6.8)$ and $5 \mathrm{~mL}$ of $0.6 \mathrm{M} \mathrm{NaOH}$ solution were incorporated and $\mathrm{pH}$ was adjusted to 6.8. Finally, pancreatin $(100 \mathrm{mg} / \mathrm{mL})$ was added and left for $4 \mathrm{~h}$ at the same temperature. The complete digestion samples were further subjected to $\mathrm{N}$-nitrosodimethylamine analysis.

\section{Determination of $\mathrm{N}$-nitrosodimethylamine}

N-nitrosodimethylamine (NDMA) in samples was analyzed by HPLC (HPLC Waters Alliance 2695 with PDA and ELSD) equipped with reverse phase C18 column (150 mm x $3.9 \mathrm{~mm}, 5 \mu \mathrm{m}$ particle size) according to Krauss and Hollender (2008) with some changes. A gradient mobile phase was adopted where ratio of $0.1 \mathrm{mM}$ ammonium acetate/methanol at $85 / 15$ was increased to $0 / 100$ in $18 \mathrm{~min}$. Injection volume of sample was $20 \mu \mathrm{L}$ and mobile phase flow rate was $100 \mu \mathrm{L} / \mathrm{min}$. Standard curve was produced employing NDMA standard solutions at a concentration range of $0-10 \mathrm{mg}$ NDMA $/ \mathrm{kg}$

\section{Sensory evaluation}

Sensory evaluation was carried out on day 1 of refrigerated storage using the 9 point Hedonic Scale with 20 panelists. Frankfurters were heated by steaming and halved before serving with 3 digit random numbers. Four attributes i.e. color, texture, odor, and taste were evaluated in the numerological scale, 1 and 9 referred to dislike extremely and like extremely, respectively. Overall acceptability served as indication of preference by the panel, but it was not used to infer consumer acceptance.

\section{Statistical analysis}

Three replicates were used in the experiment. Factorial design was employed and analysis of various (ANOVA) of the obtaining data were analyzed where factors that significantly different between means were determined using Duncan's new multiple range test. Differences were considered significant at the $\mathrm{p}<0.05$ level.

\section{RESULTS AND DISCUSSION}

\section{Effects of nitrite and GP on $\mathrm{pH}$ and color}

Table 1 shows the effect of nitrite and GP on $\mathrm{pH}$ of frankfurter during storage period $(0,7,14,21$, and 28 days). The results illustrated that nitrite alone led to similar $\mathrm{pH}$ values of frankfurter at day 0 being $6.28,6.09$ and 6.23 at 50,100 and $150 \mathrm{ppm}$ of nitrite, respectively. These results are in agreement with previous report by Deda and colleagues (Deda et al., 2007). However, considering increasing the level of GP, it can be seen that $\mathrm{pH}$ value increased in concentration dependent manner with increasing levels of GP, especially when 100 and 150 ppm nitrite were combined with GP. This is thought to be a result of high $\mathrm{pH}$ of gac aril powder. The $\mathrm{pH}$ values of samples were quite stable during day 0 to day 14 but markedly decreased after two weeks (Table 1). Chilling storage at $4{ }^{\circ} \mathrm{C}$ is designed to maintain microbiological quality of processed meat where the shelf life of which is generally up to 14 days. Spoilage microorganisms, especially lactic acid producing bacteria, grow slowly and falling of $\mathrm{pH}$ observed after this period. Among different nitrite levels, $150 \mathrm{ppm}$ maintained $\mathrm{pH}$ at higher level compared to 50 and $100 \mathrm{ppm}$ after 21-day storage. Similarly, it was previously reported that sodium nitrite could inhibit growth of lactic acid bacteria isolated from vacuum-packed cooked ring sausages, the effect was very limited at 50 and $100 \mathrm{ppm}$ but strong inhibition was observed at the dose as high as $400 \mathrm{ppm}$ (Korkeala et al., 1992).GP showed little effect on $\mathrm{pH}$ values. Inhibition of $\mathrm{pH}$ changes were obtained when nitrite was added at high level.

Color $\mathrm{L}^{*}, \mathrm{a}^{*}$, and $\mathrm{b}^{*}$ values of samples were affected by both nitrite and GP content (Table 2). At high concentration of nitrite, lightness ( $\left.\mathrm{L}^{*}\right)$ increased whereas that was reduced in the presence of higher GP level. The a* (redness) and $b^{*}$ (yellowness) values, on the other hand, increased significantly with increasing GP content. These results indicate that the color of meat product is more red-yellow in the presence of GP. This was not surprising because GP is a rich source of lycopene compared to other natural sources, 70 times more than tomato (Ishida et al., 2003). Tonucci and colleagues reported, in the tomato pulp powder, that lycopene is the predominant carotenoid responsible for the red color of the powder and its derived products (Tonucci $\boldsymbol{e t}$ al., 1995). However, the added GP increased $b *$ value which inferred that the products was more likely in orange color. The orange color developed is possibly a result of reaction between fat and lycopene which may turn lycopene from a reddish color into yellow as also reported by Hayes $\boldsymbol{e t}$ al. (2013). Moreover, following 28-day storage there were obvious changes of lightness $\left(\mathrm{L}^{*}\right)$, redness $\left(\mathrm{a}^{*}\right)$ and yellowness $\left(\mathrm{b}^{*}\right)$ of frankfurter in the samples containing low levels of GP $(0$ and $2 \%)$ whereas no color change was recorded in 4\% GP incorporated samples. This infers that GP improved color stability of frankfurter throughout the shelf life of product. Though natural colorant is readily for degradation, lycopene is lipid soluble pigment that considerably highly stable. It is well established that the most important factors in food processing that cause degradation of lycopene are heat light and oxygen (Shi et al., 1999). During storage of frankfurter, destruction of lycopene was retarded because oxygen was excluded under vacuum packaging and temperature was well controlled at $4{ }^{\circ} \mathrm{C}$.

\section{Effects of nitrite and GP on lipid oxidation}

Addition of nitrite at low levels did not affect lipid oxidation of frankfurter as indicated by TBARS values ( $\mathrm{p}>0.05$ ) (Table 3 ). Lin and colleagues (Lin et al., 2011) reported, in different meat product, that nitrite led to a significant reduction of TBARS values. Study in Italian sausage, de Oliveira et al. (2011) found that without antioxidant incorporated, TBARS values of samples decreased when 100 $\mathrm{mg} / \mathrm{kg}$ nitrite was added. However, at $200 \mathrm{mg} / \mathrm{kg}$ nitrite, adverse effect was noted especially when nitrite was combined with antioxidant. It was suggested that the antagonistic effect observed was due to an interaction between nitrite and chemical compounds present in natural antioxidant derived from plant extract. Similarly, addition of GP tended to increase the TBARS values at the highest level studied (Table 3). The negative effects of GP on lipid oxidation are also presumably attributed to high fatty acid content of gac aril in combination with polyunsaturated fatty acids in the muscle and tissues (Buckley et al., 1989) Chemical composition of gac aril has been well established. The gac fruit aril contains $22 \%$ fatty acid by weight which composes of $32 \%$ oleic, $29 \%$ palmitic, and $28 \%$ linoleic acids (Ishida et al., 2003). From the composition of gac aril, it can be said that high fatty acid may be one of the causes of oxidation. Moreover, significant amount of lycopene in gac fruit aril might also be the case since it has been reported that $20 \mu \mathrm{g} / \mathrm{mL}$ lycopene is a pro-oxidant of triglycerides (Haila $\boldsymbol{e t}$ al., 1996). However, all treatments had TBARS value less than $2 \mathrm{mg} \mathrm{MDA} / \mathrm{kg}$ up to 28 days of storage. According to Greene and Cumuze (1982), the minimum TBARS value which causes off-flavor in meat products is $2 \mathrm{mg} \mathrm{MDA} / \mathrm{kg}$. 
Therefore, it is important to point out that GP, at the range of study, showed no major effect on lipid oxidation and as a result, no effect on sensory attribute was observed. Moreover, the TBARS values were only slightly changed until 21 days of storage and a significant increase was detected at 28 -days $(\mathrm{p}<0.05)$.

Table 1 Effect of nitrite and GP on $\mathrm{pH}$ of frankfurter products

\begin{tabular}{llccccc}
\hline Factors & \multicolumn{5}{c}{$\mathbf{p H}$} & $\mathbf{1 4}$ \\
\hline Nitrite (ppm) & $\mathbf{G P}(\mathbf{g} / \mathbf{1 0 0 g})$ & $\mathbf{0 ~ d}$ & $\mathbf{7 ~ d}$ & $\mathbf{2 1 ~ d}$ & $\mathbf{2 8 ~ d}$ \\
\hline 50 & 0 & $6.28 \pm 0.13^{\mathrm{bcB}}$ & $6.47 \pm 0.02^{\mathrm{bA}}$ & $6.70 \pm 0.09^{\mathrm{aAB}}$ & $5.43 \pm 0.14^{\mathrm{bcC}}$ & $4.83 \pm 0.04^{\mathrm{bD}}$ \\
& 2 & $6.55 \pm 0.07^{\mathrm{aA}}$ & $6.21 \pm 0.01^{\mathrm{eB}}$ & $5.67 \pm 0.06^{\mathrm{dC}}$ & $5.28 \pm 0.09^{\mathrm{cD}}$ & $4.56 \pm 0.04^{\mathrm{eE}}$ \\
& 4 & $6.28 \pm 0.12^{\mathrm{bcA}}$ & $6.32 \pm 0.03^{\mathrm{dA}}$ & $6.15 \pm 0.04^{\mathrm{bB}}$ & $5.26 \pm 0.06^{\mathrm{cC}}$ & $4.71 \pm 0.02^{\mathrm{cdD}}$ \\
& 0 & $6.09 \pm 0.14^{\mathrm{dA}}$ & $5.89 \pm 0.07^{\mathrm{fB}}$ & $5.48 \pm 0.01^{\mathrm{eC}}$ & $4.97 \pm 0.02^{\mathrm{dD}}$ & $4.23 \pm 0.05^{\mathrm{gE}}$ \\
& 2 & $6.30 \pm 0.02^{\mathrm{bcA}}$ & $6.35 \pm 0.06^{\mathrm{cdA}}$ & $6.02 \pm 0.01^{\mathrm{cB}}$ & $4.86 \pm 0.64^{\mathrm{dC}}$ & $4.58 \pm 0.05^{\mathrm{eD}}$ \\
& 4 & $6.41 \pm 0.11^{\mathrm{abB}}$ & $6.67 \pm 0.04^{\mathrm{aA}}$ & $6.21 \pm 0.04^{\mathrm{bB}}$ & $5.45 \pm 0.23^{\mathrm{bcC}}$ & $4.93 \pm 0.02^{\mathrm{aD}}$ \\
& 0 & $6.23 \pm 0.10^{\mathrm{dAB}}$ & $6.40 \pm 0.01^{\mathrm{bcA}}$ & $6.14 \pm 0.05^{\mathrm{bB}}$ & $5.74 \pm 0.23^{\mathrm{aC}}$ & $4.77 \pm 0.06^{\mathrm{bCD}}$ \\
& 2 & $6.30 \pm 0.010^{\mathrm{bcB}}$ & $6.47 \pm 0.04^{\mathrm{bA}}$ & $6.17 \pm 0.03^{\mathrm{bC}}$ & $5.56 \pm 0.09^{\mathrm{abD}}$ & $4.42 \pm 0.06^{\mathrm{fE}}$
\end{tabular}

${ }^{\mathrm{abc} M e a n}$ values in the same column bearing different superscripts are significantly different $(\mathrm{p}<0.05)$.

${ }^{\mathrm{ABC}}$ Mean values in the same row bearing different superscript are significantly different $(\mathrm{p}<0.05)$.

\section{Effects of nitrite and GP on N-nitrosodimethylamine}

Nitrite is converted to nitric oxide when antioxidant such as ascorbic or caffeic acid is incorporated hence formation of nitrosamine is limited. The findings in the current study demonstrated that NDMA was not detected before in vitro digestion application (Table 4) implying that formation of NDMA requires the acid condition of gastric as reported by Meineri and colleagues (Meineri $\boldsymbol{e t}$ al. 2013). However, prior to gastric digestion system, NDMA was generated. As expected, increasing level of nitrite led to elevation of NDMA content in samples ( $\mathrm{p}<0.05$ ). Surprisingly, the addition of GP tended to increase NDMA value however, without statistical significance $(p>0.05)$. Similar results were reported by Biaudet et al. (1996). It was suggested that nitrogen oxide, a product from reduction of nitrite, can further react with unsaturated lipids and results in transnitrosation of secondary amine. Therefore, in a corporation with high fatty acid content of GP, nitrite enhanced NDMA formation. In addition, Combet $\boldsymbol{e}$ al. (2007) also reported the results of in vitro assay that ascorbic acid inhibited NDMA formation by 5 folds in aqueous solution. However, addition of $10 \%$ lipid converted ascorbic acid from inhibiting to promoting nitrosation. This may be explained by nitric oxide, formed by ascorbic acid, can regenerate nitrosating species by reacting with oxygen in the lipid phase. Moreover, it can be seen that increasing of nitrosamine content in the presence of antioxidant was concentration dependent (Table 4). Walter et al. (1976) reported that $\mathrm{N}$ nitrosopyrrolidine (NPYR) in fried bacon was suppressed when ascorbate was incorporated at a low concentration of $300 \mathrm{mg} / \mathrm{kg}$ while adverse effect was observed at the higher level. Obviously, high concentration of antioxidant leads to increasing production of nitric oxide and simultaneously promote the reaction with unsaturated lipids and as a result secondary amine reaction increased.

\section{Sensory evaluations of frankfurter products}

The results of sensory evaluation (Table 5) showed that nitrite and GP had a marked significant effect $(\mathrm{p}<0.05)$ on color of products whereas taste, texture and overall acceptance were slightly different and no effect on odor was observed Addition of GP increased acceptability of color and texture but slightly lower the score of product taste $(\mathrm{p}<0.05)$. The results of greater color acceptability as affected by GP is inferring that the red-yellow color of frankfurters was preferable. However, the taste of the frankfurter, on the other hand, was lower when $4 \%$ GP was incorporated and the results indicated that taste of frankfurter affected overall acceptability the most, as can be seen from the highest and lowest overall acceptability were noted in the sample that had the highest and lowest taste score, respectively. The reason for lower taste score in the presence of GP was thought to be due to the unique flavor of gac aril which might interact with flavoring agents added into frankfurter according to standard recipe. However, this could be easily overcome by adjusting the content of herbs and spices.

Table 2 Effect of interaction between nitrite and GP on color parameters ( $\mathrm{L}^{*}, \mathrm{a}^{*}$ and $\mathrm{b}^{*}$ ) of frankfurter products

\begin{tabular}{|c|c|c|c|c|c|c|c|}
\hline \multicolumn{2}{|l|}{ Factors } & \multicolumn{2}{|c|}{$\mathbf{L}^{*}$} & \multicolumn{2}{|c|}{$\mathbf{a}^{*}$} & \multicolumn{2}{|c|}{$\mathbf{b}^{*}$} \\
\hline $\begin{array}{l}\text { Nitrite } \\
(\mathrm{mg} / \mathrm{kg})\end{array}$ & GP(g/100g) & $\mathbf{0}$ d & $28 \mathrm{~d}$ & $\mathbf{0} \mathbf{d}$ & $28 \mathrm{~d}$ & $\mathbf{0} \mathrm{d}$ & $28 \mathrm{~d}$ \\
\hline \multirow[t]{3}{*}{50} & 0 & $58.69 \pm 1.31^{\mathrm{c}}$ & $58.72 \pm 0.70^{\mathrm{ans}}$ & $6.53 \pm 0.24^{\mathrm{e}}$ & $4.87 \pm 0.88^{\mathrm{c}^{*}}$ & $10.74 \pm 0.69^{\mathrm{e}}$ & $12.03 \pm 0.41^{\mathrm{c}^{*}}$ \\
\hline & 2 & $55.23 \pm 0.48^{\mathrm{d}}$ & $55.24 \pm 1.13^{\mathrm{bns}}$ & $19.58 \pm 0.61^{b}$ & $17.59 \pm 0.47^{\mathrm{b}^{*}}$ & $23.74 \pm 0.94^{\mathrm{b}}$ & $23.20 \pm 0.22^{\mathrm{bns}}$ \\
\hline & 4 & $53.12 \pm 1.19^{\mathrm{e}}$ & $51.71 \pm 1.20^{\mathrm{cns}}$ & $23.04 \pm 0.75^{\mathrm{a}}$ & $22.87 \pm 1.72^{\mathrm{ans}}$ & $24.92 \pm 0.86^{\mathrm{b}}$ & $26.00 \pm 1.39^{\mathrm{ans}}$ \\
\hline \multirow[t]{3}{*}{100} & 0 & $63.05 \pm 1.05^{\mathrm{b}}$ & $60.86 \pm 1.04^{\mathrm{a}^{*}}$ & $5.56 \pm 0.13^{\mathrm{e}}$ & $5.79 \pm 0.28^{\mathrm{c}^{*}}$ & $10.93 \pm 0.46^{\mathrm{e}}$ & $11.91 \pm 0.36^{\mathrm{cns}}$ \\
\hline & 2 & $56.23 \pm 0.73^{d}$ & $55.20 \pm 1.73^{\text {bns }}$ & $18.26 \pm 0.33^{\mathrm{c}}$ & $18.95 \pm 0.50^{\mathrm{bns}}$ & $22.33 \pm 1.17^{\mathrm{c}}$ & $23.40 \pm 0.91^{\text {bns }}$ \\
\hline & 4 & $52.99 \pm 0.70^{\mathrm{e}}$ & $53.78 \pm 2.07^{\text {bcns }}$ & $23.71 \pm 0.83^{\mathrm{a}}$ & $22.03 \pm 2.02^{\mathrm{ans}}$ & $26.46 \pm 1.04^{\mathrm{a}}$ & $24.64 \pm 1.08^{\mathrm{abns}}$ \\
\hline \multirow[t]{3}{*}{150} & 0 & $65.79 \pm 1.03^{\mathrm{a}}$ & $60.61 \pm 0.32^{\mathrm{a}^{*}}$ & $5.72 \pm 0.19^{\mathrm{e}}$ & $5.87 \pm 0.22^{\mathrm{cns}}$ & $8.25 \pm 0.08^{\mathrm{f}}$ & $10.68 \pm 0.41^{\mathrm{c}^{*}}$ \\
\hline & 2 & $58.74 \pm 1.19^{\mathrm{c}}$ & $54.08 \pm 1.22^{\mathrm{bc}^{*}}$ & $12.99 \pm 0.53^{\mathrm{d}}$ & $17.19 \pm 1.54^{\mathrm{b}^{*}}$ & $17.63 \pm 0.86^{\mathrm{d}}$ & $24.39 \pm 1.58^{\mathrm{ab}^{*}}$ \\
\hline & 4 & $54.94 \pm 0.65^{\mathrm{d}}$ & $53.30 \pm 2.43^{\text {bcns }}$ & $22.88 \pm 0.91^{\mathrm{a}}$ & $22.26 \pm 3.08^{\mathrm{ans}}$ & $25.10 \pm 1.33^{\mathrm{b}}$ & $26.17 \pm 1.84^{\mathrm{ans}}$ \\
\hline
\end{tabular}

${ }^{a b c}$ Mean values in the same column bearing different superscripts are significantly different $(\mathrm{p}<0.05)$.

*=Mean values are significant different between 0 and 28 -day $(\mathrm{p}<0.05)$.

ns=non-significant difference between 0 and 28-day 
Table 3 Effect of nitrite and GP on TBARS value (mg MDA/kg sample) in frankfurter products

\begin{tabular}{|c|c|c|c|c|c|c|}
\hline \multicolumn{2}{|l|}{ Factors } & \multicolumn{5}{|c|}{ TBARS (mg MDA/kg) } \\
\hline Nitrite $(\mathrm{mg} / \mathrm{kg})$ & GP(g/100g) & $\mathbf{0 d}$ & $7 \mathrm{~d}$ & $14 \mathrm{~d}$ & $21 \mathrm{~d}$ & $28 \mathrm{~d}$ \\
\hline \multirow{3}{*}{50} & 0 & $0.99 \pm 0.11^{\mathrm{cB}}$ & $1.13 \pm 0.12^{\mathrm{cB}}$ & $1.02 \pm 0.02^{\mathrm{eB}}$ & $1.27 \pm 0.23^{\mathrm{dB}}$ & $2.23 \pm 0.04^{\mathrm{cdA}}$ \\
\hline & 2 & $1.48 \pm 0.06^{\mathrm{bD}}$ & $1.77 \pm 0.02^{\mathrm{abC}}$ & $1.25 \pm 0.09^{\mathrm{cdeE}}$ & $1.98 \pm 0.15^{\mathrm{bB}}$ & $2.08 \pm 0.01^{\mathrm{dA}}$ \\
\hline & 4 & $1.86 \pm 0.20^{\mathrm{aCD}}$ & $2.08 \pm 0.06^{\mathrm{aBC}}$ & $1.47 \pm 0.06^{\mathrm{bcD}}$ & $2.47 \pm 0.45^{\mathrm{aAB}}$ & $2.73 \pm 0.19^{\mathrm{aA}}$ \\
\hline \multirow[t]{3}{*}{100} & 0 & $1.10 \pm 0.01^{\mathrm{cC}}$ & $1.36 \pm 0.06^{\mathrm{bcB}}$ & $1.08 \pm 0.06^{\mathrm{eC}}$ & $1.35 \pm 0.02^{\mathrm{cdB}}$ & $2.26 \pm 0.20^{\operatorname{cdA}}$ \\
\hline & 2 & $1.42 \pm 0.07^{\mathrm{bBC}}$ & $1.48 \pm 0.26^{\mathrm{bcB}}$ & $1.20 \pm 0.17^{\mathrm{cdeC}}$ & $1.47 \pm 0.05^{\mathrm{cdB}}$ & $2.34 \pm 0.05^{\mathrm{bcdA}}$ \\
\hline & 4 & $1.71 \pm 0.23^{\mathrm{aB}}$ & $1.71 \pm 0.09^{\mathrm{abB}}$ & $1.70 \pm 0.16^{\mathrm{abB}}$ & $1.63 \pm 0.05^{\mathrm{bcB}}$ & $2.45 \pm 0.21^{\mathrm{abcA}}$ \\
\hline \multirow[t]{3}{*}{150} & 0 & $1.45 \pm 0.05^{\mathrm{bC}}$ & $1.53 \pm 0.10^{\mathrm{bcC}}$ & $1.13 \pm 0.16^{\mathrm{deD}}$ & $1.91 \pm 0.19^{\mathrm{bB}}$ & $2.57 \pm 0.18^{\mathrm{abA}}$ \\
\hline & 2 & $1.86 \pm 0.12^{\mathrm{aAB}}$ & $1.82 \pm 0.72^{\mathrm{abB}}$ & $1.44 \pm 0.09^{\mathrm{bcdB}}$ & $1.94 \pm 0.05^{\mathrm{bAB}}$ & $2.48 \pm 0.17^{\mathrm{abcA}}$ \\
\hline & 4 & $1.91 \pm 0.11^{\mathrm{aB}}$ & $1.86 \pm 0.34^{\mathrm{abB}}$ & $1.81 \pm 0.42^{\mathrm{aB}}$ & $2.57 \pm 0.09^{\mathrm{aA}}$ & $2.64 \pm 0.07^{\mathrm{aA}}$ \\
\hline
\end{tabular}

${ }^{a b c}$ Mean values in the same column bearing different superscripts are significantly different $(\mathrm{p}<0.05)$

${ }^{A B C}$ Mean values in the same row bearing different superscript are significantly different $(\mathrm{p}<0.05)$.

Table 4 Effect of nitrite and GP on N-nitrosodimethylamine contents (mg NDMA/kg sample) in frankfurter products

\begin{tabular}{|c|c|c|c|}
\hline \multicolumn{2}{|l|}{ Factors } & \multicolumn{2}{|c|}{ NDMA (mg /kg) } \\
\hline Nitrite (mg/kg) & GP $(g / 100 g)$ & Before in vitro digestion & After in vitro digestion \\
\hline \multirow[t]{3}{*}{50} & 0 & ND & $2.48 \pm 0.76^{\mathrm{ab}}$ \\
\hline & 2 & ND & $3.21 \pm 0.94^{\mathrm{abc}}$ \\
\hline & 4 & ND & $2.88 \pm 0.94^{\mathrm{abc}}$ \\
\hline \multirow[t]{3}{*}{100} & 0 & ND & $2.17 \pm 0.32^{\mathrm{c}}$ \\
\hline & 2 & ND & $1.69 \pm 0.01^{\mathrm{c}}$ \\
\hline & 4 & ND & $2.38 \pm 0.33^{\mathrm{c}}$ \\
\hline \multirow[t]{3}{*}{150} & 0 & ND & $3.30 \pm 0.10^{\mathrm{abc}}$ \\
\hline & 2 & ND & $4.19 \pm 0.90^{\mathrm{ab}}$ \\
\hline & 4 & ND & $4.26 \pm 1.13^{\mathrm{a}}$ \\
\hline
\end{tabular}

${ }^{a b c}$ Mean values in the same column bearing different superscripts are significantly different $(\mathrm{p}<0.05)$.

$\mathrm{ND}=$ Not detectable

Table 5 Effect of nitrite and GP on sensory quality of frankfurters

\begin{tabular}{llccccc}
\hline Nitrite (mg/kg) & GP(g/100g) & Color & Odor & Taste & Texture & $\begin{array}{c}\text { Overall } \\
\text { acceptability }\end{array}$ \\
\hline 50 & 0 & $5.10 \pm 1.68^{\mathrm{bc}}$ & $5.30 \pm 1.75^{\mathrm{ns}}$ & $5.85 \pm 1.78^{\mathrm{a}}$ & $4.85 \pm 1.76^{\mathrm{ab}}$ & $5.85 \pm 1.39^{\mathrm{a}}$ \\
50 & 2 & $6.50 \pm 1.47^{\mathrm{a}}$ & $5.50 \pm 1.64^{\mathrm{ns}}$ & $3.95 \pm 1.47^{\mathrm{bc}}$ & $4.15 \pm 1.70^{\mathrm{ab}}$ & $4.85 \pm 1.27^{\mathrm{ab}}$ \\
50 & 4 & $5.95 \pm 1.85^{\mathrm{ab}}$ & $5.35 \pm 1.81^{\mathrm{ns}}$ & $5.00 \pm 1.72^{\mathrm{ab}}$ & $5.10 \pm 1.94^{\mathrm{a}}$ & $5.40 \pm 1.96^{\mathrm{ab}}$ \\
100 & 0 & $4.65 \pm 1.18^{\mathrm{c}}$ & $5.35 \pm 1.78^{\mathrm{ns}}$ & $4.85 \pm 1.60^{\mathrm{abc}}$ & $4.70 \pm 2.05^{\mathrm{ab}}$ & $4.90 \pm 1.48^{\mathrm{ab}}$ \\
100 & 2 & $6.00 \pm 1.95^{\mathrm{ab}}$ & $5.30 \pm 1.72^{\mathrm{ns}}$ & $4.65 \pm 1.42^{\mathrm{bc}}$ & $4.50 \pm 1.76^{\mathrm{ab}}$ & $5.15 \pm 1.56^{\mathrm{ab}}$ \\
100 & 4 & $5.70 \pm 1.75^{\mathrm{abc}}$ & $5.25 \pm 1.37^{\mathrm{ns}}$ & $4.45 \pm 1.90^{\mathrm{bc}}$ & $4.75 \pm 2.07^{\mathrm{ab}}$ & $4.80 \pm 1.83^{\mathrm{ab}}$ \\
150 & 0 & $4.70 \pm 1.62^{\mathrm{c}}$ & $5.45 \pm 1.76^{\mathrm{ns}}$ & $4.40 \pm 1.70^{\mathrm{bc}}$ & $3.75 \pm 1.48^{\mathrm{b}}$ & $4.75 \pm 1.48^{\mathrm{ab}}$ \\
150 & 2 & $5.05 \pm 2.11^{\mathrm{bc}}$ & $4.65 \pm 1.78^{\mathrm{ns}}$ & $4.20 \pm 1.80^{\mathrm{bc}}$ & $4.05 \pm 2.00^{\mathrm{ab}}$ & $4.75 \pm 1.80^{\mathrm{ab}}$ \\
150 & 4 & $5.80 \pm 1.85^{\mathrm{abc}}$ & $4.85 \pm 1.81^{\mathrm{ns}}$ & $3.70 \pm 1.87^{\mathrm{c}}$ & $3.90 \pm 1.62^{\mathrm{ab}}$ & $4.25 \pm 1.77^{\mathrm{b}}$ \\
\hline${ }^{\mathrm{abc}}$ Mean values in the same column bearing different superscripts are significantly different $(\mathrm{p}<0.05)$.
\end{tabular}

$\mathrm{NS}=$ Non-significant

\section{CONCLUSION}

GP successfully improved the color of frankfurter as can be observed from the results of sensory evaluation and supported by increasing of $\mathrm{a}^{*}$ and $\mathrm{b}^{*}$ values. However, high level of GP had slight effect to increase TBARS value and $\mathrm{N}$ nitrosodimethylamine content in the products. Finally, it can be concluded that GP is an alternative way to improve color of frankfurter products. Nonetheless, the addition of GP more than $2 \mathrm{~g} / 100 \mathrm{~g}$ may increase lipid oxidation and $\mathrm{N}$ nitrosodimethylamine formation.

Acknowledgments: The authors would like to thank Laemthong Food Products Co.Ltd. (Food Products Business) for financial support. Thanks also goes to Mae Fah Luang Unversity for providing technical support.

\section{REFERENCES}

Aust, O., Ale-Agha, N., Zhang, L., Wollersen, H., Sies, H. \& Stahl, W. (2003) Lycopene oxidation product enhances gap junctional communication. Food Chemistry, 41, 1399-407.http://dx.doi.org/10.1016/s0278-6915(03)00148-0

Biaudet, H., Pignatelli , B. \& Debry, G. (1996). N-nitroso compounds. Hand book of food analysis. New York:Marcel Dekker.

Boisen, S.\& Fernandez, J. A. (1997). Prediction of the total tract digestibility of energy in feedstuffs and pig diets by in vitro analyses. Anim. Feed Sci. Technol, 68, 277-286.http://dx.doi.org/10.1016/s0377-8401(97)00058-8
Buckley, D.J., Gtay, J.I., Asghar, A., Booren, A.M., Crackel, R.L., Price, J.F.\& Miller, E. R. (1989). Effects of dietary antioxidants and oxidised oil on membranol lipid stability pork product quality. Journal of Food Science, 54 1193-7.http://dx.doi.org/10.1111/j.1365-2621.1989.tb05952.x

Combet, E., Paterson, S., Iijima, K., Winter, J. Mullen, W,. Crozier, A., Preston, T.\& McColl K.E.L. (2007). Fat transforms ascorbic acid from inhibiting to promoting acid-catalysed N-nitrosation. Gut, 56(12), 1678-1684 http://doi.org/10.1136/gut.2007.128587

Deda, M.S., Bloukas, J. G. \& Fista, G.A. (2007). Effect of tomato paste and nitrite level on processing and quality characteristics of frankfurters. Meat Science, 76(3),501-508. http://dx.doi.org/10.1016/j.meatsci.2007.01.004

de Oliveiraa, T. L. C., de Carvalhob, S. M., de Araújo Soaresa, R., Andradeb, M. A., Cardosob, G., Ramosc, E. M. \& Piccolia, R. H. Antioxidant effects of Satureja montana L. Essentail oil on TBARS and color of mortadella-type sausages formulated with different levels of sodium nitrite. LWT - Food Science and Technology, 45 (2), 204-212.http://dx.doi.org/10.1016/j.lwt.2011.09.006

Eyiler, E. \& Oztan, A. (2011). Production of frankfurters with tomato powder as a natural additive. LWT - Food Science and Technology, 44(1), 307 311.http://dx.doi.org/10.1016/j.lwt.2010.07.004

Feiner, G. (2006). Meat products handbook: practical science and technology.England:Woodhead

Ltd.http://dx.doi.org/10.1201/9781439824245

FAO/WHO. (1996).Toxicological evaluation of certain food additives and contaminants. Geneva. World Health Organization, Joint FAO/WHO Expert 
Committee on Food Additives, WHO Food Additives Series No. 35, Geneva, Switzerland.

Nollet, L.M.L.\& Toldra, F. (2009). Handbook of Processed Meats and Poultry Analysis. New York: CRC press.http://dx.doi.org/10.1201/9781420045338

Greene, B. E. \& Cumuze, T.H. (1982). Relationship between TBA numbers and inexperienced panelists' assessments of oxidized flavor in cooked beef. Journal of Food Science, 47(1), 52-4.http://dx.doi.org/10.1111/j.13652621.1982.tb11025.x

Haila, K.M., Lievonen, S. M. \& Heinonen, M.I. (1996). Effects of lutein, lycopene, annatto, and $\gamma$-tocopherol on autoxidation of triglycerides. Journal of $\begin{array}{lll}\text { Agricultural Food Chemistry, 44(8),2096- } & \end{array}$ 1000.http://dx.doi.org/10.1021/jf9504935

Hayes, J.E., Canonico, I. \& Allen, P. (2013). Effects of organic tomato pulp powder and nitrite level on the physicochemical, textural and sensory properties of pork luncheon roll. Meat Science, 95(3), 755 762.http://dx.doi.org/10.1016/j.meatsci.2013.04.049

Ishida, B.K., Turner, C., Chapman, M.H.\& McKeon, T.A. (2003). Fatty acid and carotenoid composition of gac (Momordica cochinchinensis Spreng) fruit Journal of Agricultural and Food Chemistry,52(2), 274 279.http://dx.doi.org/10.1021/jf030616i

Jensen, C., Lauridsen, C. \& Bertelsen, G. (1998). Dietary vitamin E: Quality and storage stability of pork and poultry. Trends in Food Science \&Technology, 9(2),62-72.http://dx.doi.org/10.1016/S0924-2244(98)00004-1

Kha, T.C., Nguyen, M.H., Roach, P. D. \& Stathopoulos, C.E. (2014)

Microencapsulation of gac oil: optimisation of spray drying conditions using response surface methodology. Powder Technology, 264,298309.http://dx.doi.org/10.1016/j.powtec.2014.05.053

Kha,T.C., Nguyen, M.H., Roach, P. D. \& Stathopoulos, C.E.(2015). A storage study of encapsulated gac (Momordicacochinchinensis) oil powder and its fortification into foods.Food and Bioproducts Processing, 96:113125.http://dx.doi.org/10.1016/j.fbp.2015.07.009

Korkeala, H., Alanko, T. \&Tiusanen T. (1992). Effect of sodium nitrite and sodium chloride on growth of lactic acid bacteria.Acta Vet Scand. 33(1), 27-32.

Krauss, M.\& Hollender, J. (2008). Analysis of nitrosamines in wastewater: exploring the trace level quantification capabilities of a hybrid linear ion trap/orbitrap mass spectrometer. Analytical Chemistry, 80(3), 834842.http://dx.doi.org/10.1021/ac701804y

Kubola, J. \& Siriamornpun, S. (2011). Phytochemicals and antioxidant activity of different fruit fractions (peel, pulp, aril and seed) of Thai gac (Momordica cochinchinensis Spreng). Food Chem, 27(3),1138-45. http://dx.doi.org/10.1016/j.foodchem.2011.01.115

Lin, Y., Huang, M., Zhou, G., Zou, Y.\& Xu, X. (2011). Prooxidant effects of the combination of green tea extract and sodium nitrite for accelerating lipolysis and lipid oxidation in pepperoni during storage. Journal of Food Science, 76(5):C694-C700.http://dx.doi.org/10.1111/j.1750-3841.2011.02187.x

Meineri, G., Medana, C., Giancotti, V., Visentin, S. \& Peiretti, P.G. (2013), Effect of dietary supplementation of vitamin $\mathrm{E}$ in pigs to prevent the formation of carcinogenic substances in meat products. Journal of Food Composition and Analysis, 30(2), 67-72.http://dx.doi.org/10.1016/j.jfca.2013.02.002

Ohshima, H. ,\& Bartsch, H. (1999). Quantitative estimation of endogenous nitrosation in humans by monitoring $\mathrm{N}$-nitrosoproline excreted in the urine Nitric Oxide Part C: Biological and Antioxidant Activities, 4049.http://dx.doi.org/10.1016/s0076-6879(99)01067-8

Shi, J., Maguer, M. L., Kakuda, Y., Liptay, A., \& Niekamp, F. (1999). Lycopene degradation and isomerization in tomato dehydration.

$$
\text { Food Research International, 32, 15- }
$$

21.http://dx.doi.org/10.1016/S0963-9969(99)00059-9

Tonucci, L.H., Holden, J.M., Beecher, G.R., Khachik, F., Davis, C. S. \& Mulokozi, G. (1995). Carotenoid content of thermally processed tomato-based food products. Journal of Agricultural and Food Chemistry, 43(3), 579586.http://dx.doi.org/10.1021/jf00051a005

West, C.E.\& Poortvliet, E.J. (1993). The carotenoid content of foods with special reference to developing countries. Institute IsaT: Virginia.

Walters, C. L., Edwards, M. W., Elsey, T. S. \& Martin, M. (1976).The effect of antioxidants on the production of volatile nitrosamines during the frying of bacon. Z LebensmUntersForsch. $162(4), \quad 377$ 385.http://dx.doi.org/10.1007/bf01122791 